\title{
PENGARUH MODEL PEMBELAJARAN DISCOVERY-INQUIRY TERBIMBING DAN BEBAS TERMODIFIKASI DITINJAU DARI SIKAP ILMIAH TERHADAP PRESTASI BELAJAR SISWA PADA MATERI HIDROLISIS GARAM KELAS XI SEMESTER GENAP SMA N 1 BOYOLALI TAHUN PELAJARAN 2016/2017
}

\author{
Vonia Suci Widiastuti, Elfi Susanti $\mathbf{V H}^{\star}$, dan Endang Susilowati \\ Program Studi Pendidikan Kimia, FKIP,Universitas Sebelas Maret, Surakarta, Indonesia \\ “Keperluan korespondensi, HP 08121523622, e-mail: bunda3f@gmail.com
}

\begin{abstract}
ABSTRAK
Penelitian ini bertujuan untuk mengetahui: (1) pengaruh penerapan model pembelajaran discovery-inquiry terbimbing dan bebas termodifikasi terhadap prestasi belajar siswa pada materi hidrolisis garam; (2) pengaruh sikap ilmiah tinggi dan rendah terhadap prestasi belajar siswa pada materi hidrolisis garam; dan (3) interaksi antara model pembelajaran discovery-inquiry terbimbing dan bebas termodifikasi terhadap prestasi belajar siswa pada materi hidrolisis garam. Penelitian ini merupakan penelitian kuantitatif dengan metode eksperimen desain faktorial $2 \times 2$. Sampel terdiri dari 2 kelas yang dipilih menggunakan teknik cluster random sampling. Sampel penelitian yaitu kelas XI MIA 1 (discovery-inquiry terbimbing) dan kelas XI MIA 2 (discovery-inquiry bebas termodifikasi). Pengumpulan data dilakukan melalui studi dokumentasi, tes, angket dan observasi. Teknik analisis data yang digunakan adalah uji non parametrik dengan uji Mann Whitney dan Kruskall Wallis yang terdapat dalam software SPSS 23 dengan taraf signifikansi $5 \%$. Hasil penelitian menunjukkan bahwa: 1) tidak ada pengaruh model pembelajaran discovery-inquiry terbimbing dan bebas termodifikasi terhadap prestasi aspek pengetahuan, sikap dan keterampilan terhadap prestasi belajar siswa; (2) terdapat pengaruh sikap ilmiah tinggi dan rendah terhadap prestasi aspek keterampilan, sedangkan pada prestasi aspek pengetahuan dan sikap tidak ada pengaruh sikap ilmiah tinggi dan rendah; dan (3) tidak ada interaksi antara penggunaan model pembelajaran discovery-inquiry terbimbing dan bebas termodifikasi dengan sikap ilmiah terhadap prestasi belajar siswa.
\end{abstract}

Kata kunci: Discovery-inquiry terbimbing, discovery-inquiry bebas termodifikasi, sikap ilmiah, prestasi belajar, metode eksperimen.

\section{PENDAHULUAN}

Pendidikan pada pokoknya adalah suatu proses untuk membantu manusia dalam mengembangkan dirinya, sehingga diharapkan mampu menghadapi segala perubahan dan permasalahan dengan sikap terbuka serta pendekatan kreatif tanpa kehilangan identitas dirinya. Pemerintah senantiasa berupaya untuk membangun sistem pendidikan yang berkualitas, agar anak bangsa nantinya siap bersaing dengan negara lainnya. Salah satu upaya yang dilakukan pemerintah adalah dengan penerapan kurikulum 2013.

Kurikulum 2013 merupakan kurikulum baru yang mulai diterapkan pada tahun ajaran 2013/2014 yang merupakan pengembangan dari KTSP [1]. Kurikulum 2013 adalah sebuah kurikulum yang dikembangkan untuk meningktakan dan menyeimbangkan kemampuasn soft skills yang berupa sikap, pengetahuan dan keterampilan secara terpadu [2]. Proses pembelajran yang cenderung berpusat pada guru (teacher centered) berubah menjadi berpusat pada siswa (student centered).

Kimia sebagai salah satu mata pelajaran sains berisi fakta dan konsep gejala alam yang diperoleh dari kerja dan proses ilmiah yang dilakukan oleh ilmuwan. Pembelajaran kimia menekankan pada pembentukan konsep menggunakan keterampilan proses sains dan 
sikap ilmiah dalam kegiatan-kegiatan belajar yang dilakukan.

Pembelajaran kimia dan sains sebagian besar masih dilakukan dengan tidak melibatkan partisipasi aktif dari siswa. Fenomena yang sering terlihat dalam pembelajaran adalah: strategi pembelajaran yang kurang tepat; mengandalkan LKS yang dijual penerbit tertentu; sains disajikan secara teoritis; belum menggunakan laboratorium secara optimal [3]. Guru lebih mengutamakan pemberian pengetahuan secara formatif saja dan kurang memberikan ruang yang bebas bagi siswa untuk melakukan penyelidikan, serta mengembangkan cara berpikir objektif dan kritis analitis. Beberapa hal tersebut menunjukkan bahwa pembelajaran yang dilakukan masih terpusat pada guru.

Kondisi tersebut juga terjadi di SMA N 1 Boyolali. SMA Negeri 1 Boyolali merupakan salah satu sekolah Negeri di kota Boyolali yang dalam kegiatan belajar mengajar telah menerapkan kurikulum 2013. Berdasarkan hasil observasi selama Praktek Pengalaman Lapangan (PPL) pada bulan September-November 2016, pembelajaran kimia yang dilakukan guru masih menggunakan metode ceramah, tanya jawab, dan penugasan dibantu dengan media presentasi. Ketersediaan media, alat peraga sudah cukup lengkap dan terawat dengan baik, namun frekuensi penggunaannya belum optimal, tidak jarang pula guru tidak menggunakan media. Pembelajaran cenderung masih didominasi oleh guru dengan hanya memberikan konsep-konsep. Hal ini tentu berpengaruh terhadap proses, sikap, dan keterampilan ilmiah siswa. Pembelajaran yang terjadi belum sepenuhnya sesuai dengan Kurikulum 2013.

Hidrolisis Garam adalah salah satu materi pelajaran kimia yang dipelajari di kelas XI semester genap dalam Kurikulum 2013, termasuk materi abstrak dan berurutan sehingga untuk memahami konsep materi hidrolisis siswa harus paham terlebih dahulu subkonsep yang saling terkait dengan materi ini, diantaranya stoikiometri, larutan asambasa, dan $\mathrm{pH}$ larutan, sehingga pembelajaran yang berpusat pada guru (teacher centered) kurang efektif apabila digunakan dalam memahami konsepkonsep pada materi hidrolisis garam ini. Pembelajaran pada materi ini seharusnya siswa yang aktif (student centered) sehingga siswa mampu memahami konsep-konsep tersebut dengan mudah dan bersifat permanen.

Data Badan Standar Nasional Pendidikan tentang daya serap nilai Ujian Nasional rata-rata Kota/Kabupaten Tahun Pelajaran 2014/2015 di Boyolali pada kelompok soal KD mendeskripsikan Hidrolisis Garam dan Ksp sebesar 47,43, sedangkan nilai Ujian Nasional rata-rata propinsi dan nasional berturut-turut adalah 54,52 dan 60,36 . Nilai Ujian Nasional ratarata Kota/Kabupaten pada tahun berikutnya yaitu 2015/2016 di Boyolali pada kelompok KD yang sama sebesar 60,46 , sedangkan nilai Ujian Nasional rata-rata propinsi dan nasional berturut-turut adalah 60,76 dan 56,07. Hasil tersebut menunjukkan bahwa perolehan nilai Ujian Nasional rata-rata di Kabupaten Boyolali pada materi hidrolisis garam masih belum memuaskan meskipun terjadi peningkatan nilai tahun pelajaran 2015/2016 pada tingkat nasional tetapi jika dilihat belum seluruhnya diatas rata-rata nilai tingkat provinsi dan nasional. Dari data tersebut juga mengindikasi bahwa materi hidrolisis garam merupakan materi yang sulit bagi siswa.

Materi hidrolisis garam merupakan materi kimia yang memuat pemahaman konseptual dan pemahaman algoritmik yang dapat disampaikan melalui kegiatan ilmiah seperti eksperimen. Eksperimen hidrolisis garam mudah dilakukan dengan alat dan bahan yang ada di laboratorium. Sehingga penyampaian materi akan lebih bermakna jika pembelajaran dikemas dalam model pembelajaran yang melibatkan eksperimen dan penguatan konsep. Berdasarkan karakteristik materi tersebut sikap ilmiah menjadi salah satu faktor internal dalam diri siswa yang penting dalam mempelajari materi hidrolisis garam.

Sikap ilmiah dalam mempelajari kimia sangat bermanfaat bagi siswa yaitu dapat membentuk sikap dan nilai positif dalam diri siswa antara lain rasa percaya diri yang tinggi, ketekunan, kecermatan, pekerja keras, dan tak kenal putus asa [4]. 
Siswa dengan sikap ilmiah tinggi, mempunyai rasa ingin tahu besar dan termotivasi dalam pembelajaran kimia. Mereka juga akan terlibat aktif falam proses pembelajaran untuk menemukan pengetahuan baru [5].

Pembelajaran kimia menuntut siswa untuk mendapatkan produk-produk ilmiah melalui proses-proses ilmiah yang dilandasi oleh sikap-sikap ilmiah maka diperlukan model yang dapat mengembangkan tiga aspek ini. Salah satu model pembelajaran yang dapat digunakan adalah model discovery-inquiry. Model pembelajaran discovery-inquiry merupakan model pembelajaran yang mengarahkan siswa pada kegiatan yang dapat mengembangkan sikap ilmiah. Siswa dibimbing untuk menemukan dan menyelidiki sendiri tentang suatu konsep sains sehingga pengetahuan dan keterampilan yang dimiliki siswa bukan hasil mengingat seperangkat fakta melainkan hasil temuan mereka sendiri.

Model pembelajaran yang digunakan dalam penelitian ini adalah model discovery-inquiry learning yang dikelompokkan menjadi discovery-inquiry terbimbing dan bebas termodifikasi. Model discovery-inquiry learning merupakan penggabungan dari model penemuan (discovery) dan model penyelidikan (inquiry) [6]. Kedua model pembelajaran ini memiliki tujuan yang sama yaitu mengarahkan dan membimbing siswa untuk dapat menemukan sendiri jawaban dari permasalahan yang diberikan.

Sintaks atau fase-fase pelaksanaan model pembelajaran discovery-inquiry terbimbing dan bebas termodfikasi pada dasarnya sama karena discovery-inquiry terbimbing dan bebas termodfikasi termasuk tipe-tipe dari model inkuiri [7]. Pembelajaran inquiry merupakan pembelajaran yang menyertakan siswa untuk aktif dalam proses belajar yang menekankan pada tanya jawab, analisa data dan berpikir kritis [8]. Perbedaan dari kedua model discovery-inquiry learning yang digunakan dalam penelitian ini adalah peran guru dan porsi guru.

Pada model discovery-inquiry terbimbing guru lebih dominan membimbing siswa, sementara pada model discovery-inquiry bebas termodifikasi guru hanya memantau dan membantu jika dibutuhkan hingga pada fase data collection [7].

Pada model discovery-inquiry terbimbing, guru memberikan persoalan dan siswa diberi tugas untuk memecahkan persoalan itu dengan prosedur tertentu yang sudah diarahkan oleh guru. Siswa dalam menyelesaikan persoalan menyesuaikan dengan prosedur yang telah ditetapkan oleh guru [9].

Pada model discovery-inquiry bebas termodifikasi guru berperan sebagai penyedia jawaban jika siswa mengajukan pertanyaan. Jika tidak ada pertanyaan dari siswa, guru hanya mengawasi proses inquiri siswa. Guru juga berperan menyediakan sarana dan prasaran penyelidikan. Siswa diharuskan merencanakan garis-garis besar prosedur penelitian hingga menarik kesimpulan, selanjutnya siswa diberi kebebasan untuk memecahkan masalah.

Beberapa penelitian telah dilakukan dengan menggunakan model pembelajaran discovery-inquiry. Penerapan metode pembelajaran Guided DiscoveryInquiry dapat meningkatkan penguasaan konsep matematika siswa kelas VII SPM N 1 Sleman [10]. Pencapaian keterampilan proses sains seluruh siswa pada pembelajaran sifat-sifat koloid dengan menggunakan model discovery-inquiry yaitu $73.7 \%$ [11]. Penerapan pembelajaran meng-gunakan penemuan terbimbing cukup efektif untuk meningkatkan pemahaman siswa dalam belajar. Hal ini ditunjukkan adanya peningkatan dari $30,77 \%$, kemudian menjadi 89,74\% [12].

Faktor-faktor yang mempengaruhi keberhasilan prestasi belajar siswa yang di teliti dalam penelitian ini antara lain model pembelajaran dan sikap ilmiah. Model pembelajaran merupakan salah satu contoh dari faktor eksternal, sedangkan sikap ilmiah merupakan faktor internal yang mempengaruhi keberhasilan prestasi belajar siswa. Faktor internal merupakan faktor yang berasal dari dalam diri siswa, sedangkan faktor eksternal merupakan faktor yang berasal dari luar diri siswa [13].

Pemilihan model dan penggunaan sikap ilmiah harus disesuaikan dengan karakteristik peserta didik, materi dan sumber daya yang ada. Dengan demikian, 
diharapkan guru dapat menyampaikan pembelajaran kimia dengan lebih interaktif, menarik serta menyenangkan bagi siswa, sehingga akan mempengaruhi prestasi belajar siswa.

Berdasarkan kajian penelitian yang telah diteliti tersebut, penulis memilih untuk mengadakan penelitian dengan model yang sama, namun dengan materi, tinjauan dan sasaran yang berbeda. Materi yang digunakan dalam penelitian ini adalah materi hidrolisis garam untuk mengetahui ada tidaknya perbedaan prestasi belajar antara siswa yang diberi model pembelajaran discovery-inquiry terbimbing dan bebas termodifikasi dan interaksinya yang ditinjau dari sikap ilmiah siswa kelas XI MIA di Sekolah Menengah Atas (SMA) N 1 Boyolali.

\section{METODE PENELITIAN}

Penelitian ini dilaksanakan di SMA N 1 Boyolali kelas XI MIA semester genap tahun pelajaran 2016/2017. Rancangan penelitian ini adalah dengan menggunakan metode eksperimen dengan desain factorial $2 \times 2$. Adapun desain penelitian disajikan pada Tabel 1.

Tabel 1. Desain Penelitian Faktorial 2x2

\begin{tabular}{|c|c|c|c|}
\hline \multirow[b]{2}{*}{$\begin{array}{c}\text { Kelas } \\
\text { Eks }\end{array}$} & \multirow{2}{*}{$\begin{array}{c}\text { Model } \\
\text { Pembelajaran } \\
(\mathrm{A})\end{array}$} & \multicolumn{2}{|c|}{ Sikap Ilmiah (B) } \\
\hline & & $\begin{array}{c}\text { Tinggi } \\
\left(B_{1}\right)\end{array}$ & $\begin{array}{l}\text { Rendah } \\
\left(\mathrm{B}_{2}\right)\end{array}$ \\
\hline I & $\begin{array}{l}\text { Discovery- } \\
\text { Inquiry } \\
\text { Terbimbing } \\
\left(\mathrm{A}_{1}\right)\end{array}$ & $A_{1} B_{1}$ & $A_{1} B_{2}$ \\
\hline II & $\begin{array}{c}\text { Discovery- } \\
\text { Inquiry Bebas } \\
\text { Termodifikasi } \\
\left(A_{2}\right)\end{array}$ & $\mathrm{A}_{2} \mathrm{~B}_{1}$ & $\mathrm{~A}_{2} \mathrm{~B}_{2}$ \\
\hline
\end{tabular}

Keterangan :

A : Model Pembelajaran

$\mathrm{A}_{1}$ : Model Pembelajaran DiscoveryInquiry Terbimbing

$\mathrm{A}_{2}$ : Model Pembelajaran DiscoveryInquiry Bebas Termodifikasi

B : Sikap Ilmiah

$\mathrm{B}_{1} \quad$ : Sikap Ilmiah Tinggi

$\mathrm{B}_{2} \quad$ : Sikap Ilmiah Rendah

$A_{1} B_{1} \quad$ : Penggunaan model discovery-inquiry terbimbing pada siswa dengan sikap ilmiah tinggi
$A_{1} B_{2} \quad$ : Penggunaan model discovery-inquiry terbimbing pada siswa dengan sikap ilmiah rendah

$\mathrm{A}_{2} \mathrm{~B}_{1} \quad$ : Penggunaan model discovery-inquiry bebas termodifikasi pada siswa dengan sikap ilmiah tinggi

$\mathrm{A}_{2} \mathrm{~B}_{2} \quad$ : Penggunaan model discovery-inquiry bebas termodifikasi pada siswa dengan sikap ilmiah rendah

Populasi dalam penelitian ini adalah seluruh siswa kelas XI MIA SMA N 1 Boyolali Semester genap tahun pelajaran 2016/2017 yang berjumlah 7 kelas, yaitu XI MIA 1, XI MIA 2, XI MIA 3, XI MIA 4, XI MIA 5, XI MIA 6, dan XI MIA 7. Sampel terdiri dari 2 kelas yang diambil menggunakan teknik cluster random sampling.

Pengumpulan data dilakukan dengan menggunakan tes untuk mengukur prestasi belajar aspek pengetahuan, angket untuk mengukur prestasi belajar aspek sikap dan sikap ilmiah, dan observasi untuk mengukur prestasi belajar aspek sikap dan keterampilan.

Sebelum eksperimen dilakukan, kelas eksperimen 1, kelas eksperimen 2, dan kelas uji coba instrumen diketahui keadaan awalnya [14]. Hal tersebut dengan tujuan agar hasil eksperimen benar merupakan akibat dari perlakuan yang telah dibuat, bukan dikarenakan pengaruh lain. Untuk menguji keadaan awal kedua kelompok sampel digunakan uji kesetaraan rata-rata $t$ independent samples test setelah terlebih dahulu diketahui bahwa populasi adalah homogen. Hipotesis penelitian ini diuji menggunakan statistik uji non parametrik Kruskall Wallis karena data tidak berdistribusi normal dan homogen.

\section{HASIL DAN PEMBAHASAN}

Deskripsi data hasil penelitian disajikan sebagai berikut:

\section{Data skor sikap ilmiah}

Skor sikap ilmiah dikategorikan tinggi apabila skor sikap ilmiah $\geq$ skor ratarata sikap ilmiah gabungan dan dikategorikan rendah apabila skor sikap ilmiah $\leq$ skor rata-rata sikap ilmiah gabungan sikap ilmiah siswa. Data sikap ilmiah siswa tersaji pada Tabel 2. 
Tabel 1. Data Skor Sikap Ilmiah

\begin{tabular}{ccc}
\hline Kategori & \multicolumn{2}{c}{ Jumlah Siswa } \\
\cline { 2 - 3 } Sikap & Kelas Eks. I & Kelas Eks. II \\
Ilmiah & & 21 \\
\hline Tinggi & 21 & 11 \\
Rendah & 11 & \\
\hline
\end{tabular}

Deskripsi data skor sikap ilmiah lebih lengkap tersaji pada Tabel 3

Tabel 2. Deskripsi Data Skor Sikap Ilmiah Siswa

\begin{tabular}{lcc}
\hline \multicolumn{1}{c}{ Aspek } & $\begin{array}{c}\text { Kelas } \\
\text { Eks. I }\end{array}$ & $\begin{array}{c}\text { Kelas } \\
\text { Eks. } \\
\text { II }\end{array}$ \\
\hline Rata-rata & 84,968 & 85,718 \\
Median & 87 & 87 \\
Nilai Tertinggi & 102 & 105 \\
Nilai Terendah & 70 & 70 \\
Standar Deviasi & 9,177 & 9,081 \\
Varians & 84,225 & 82,467 \\
\hline
\end{tabular}

\section{Data Prestasi Belajar Aspek Pengetahuan}

Pada kelas eksperimen I, nilai tertinggi prestasi pengetahuan siswa adalah 93,33 , nilai terendah 56,67 , dan nilai rata-ratanya adalah 77,40 . Pada kelas eksperimen II, nilai tertinggi prestasi pengetahuan siswa adalah 100 , nilai terendah 53,33, dan nilai rata-ratanya adalah 78,13. Perbandingan distribusi frekuensi prestasi pengetahuan tersaji pada Tabel 3, dan histogram perbandingan distribusi frekuensi nilai aspek pengetahuan pada Gambar 1.

Tabel 3. Perbandingan Distribusi Frekuensi Nilai Pengetahuan Siswa

\begin{tabular}{|c|c|c|c|}
\hline \multirow{3}{*}{ Interval } & \multirow{3}{*}{$\begin{array}{c}\text { Nilai } \\
\text { Tengah }\end{array}$} & \multicolumn{2}{|c|}{ Frekuensi } \\
\hline & & Kelas & Kelas \\
\hline & & Eks. I & Eks. II \\
\hline $52,33-59,33$ & 55,83 & 2 & 4 \\
\hline $59,67-66,67$ & 63,17 & 4 & 2 \\
\hline $67-74$ & 70,5 & 5 & 3 \\
\hline $74,33-81,33$ & 77,83 & 7 & 10 \\
\hline $81,67-88,67$ & 85,17 & 12 & 6 \\
\hline $89-96$ & 92,5 & 2 & 5 \\
\hline $96,33-103,33$ & 99,83 & 0 & 2 \\
\hline Jumlah & & 32 & 32 \\
\hline
\end{tabular}

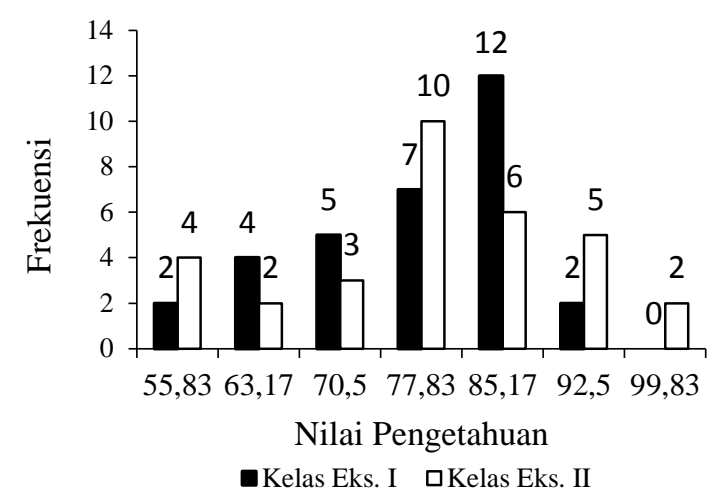

Gambar 1. Histogram Perbandingan Distribusi Frekuensi Nilai Aspek Pengetahuan Siswa

\section{Data Prestasi Belajar Aspek Sikap}

Pada kelas eksperimen I, nilai tertinggi prestasi sikap siswa adalah 4, nilai terendah 2 , dan nilai rata-ratanya adalah 2,906. Pada kelas eksperimen II, nilai tertinggi prestasi sikap siswa adalah 4, nilai terendah 3 , dan nilai rata-ratanya adalah 3,218. Perbandingan distribusi frekuensi prestasi sikap siswa tersaji pada Tabel 4, dan histogram perbandingan distribusi frekuensi nilai aspek sikap pada Gambar 2.

Tabel 4. Perbandingan Distribusi Frekuensi Nilai Sikap Siswa

\begin{tabular}{ccc}
\hline \multirow{2}{*}{ Nilai } & \multicolumn{2}{c}{ Frekuensi } \\
\cline { 2 - 3 } & Kelas Esk. I & Kelas Eks. II \\
\hline 1 & 0 & 0 \\
2 & 8 & 0 \\
3 & 19 & 25 \\
4 & 5 & 7 \\
Jumlah & 32 & 32 \\
\hline
\end{tabular}

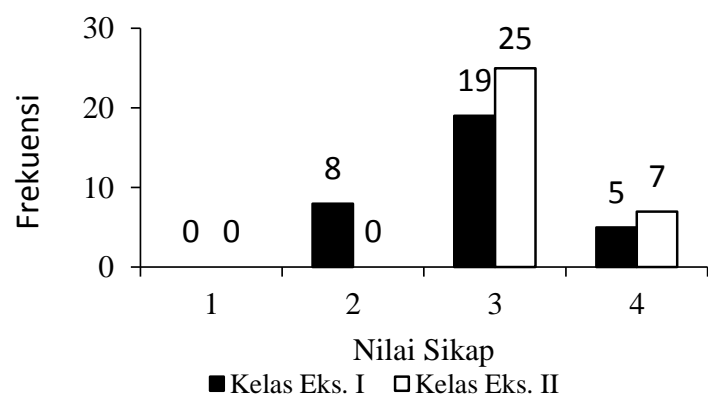

Gambar 4. Histogram Perbandingan Distribusi Frekuensi Nilai Aspek Sikap Siswa 


\section{Data Prestasi Belajar Aspek Keterampilan}

Pada kelas eksperimen I, nilai tertinggi prestasi pengetahuan keterampilan siswa adalah 3,71 , nilai terendah 2,33, dan nilai rata-ratanya adalah 3,045. Pada kelas eksperimen II, nilai tertinggi prestasi keterampilan siswa adalah 3,86 , nilai terendah 1,78 , dan nilai rata-ratanya adalah 3,15. Perbandingan distribusi frekuensi prestasi keterampilan tersaji pada Tabel 5, dan histogram perbandingan distribusi frekuensi nilai aspek keterampilan pada Gambar 3

Tabel 5. Perbandingan Distribusi Frekuensi Nilai Keterampilan Siswa

\begin{tabular}{cccc}
\hline \multirow{2}{*}{ Interval } & \multirow{2}{*}{$\begin{array}{c}\text { Nilai } \\
\text { Tengah }\end{array}$} & \multicolumn{2}{c}{ Frekuensi } \\
\cline { 3 - 4 } & & $\begin{array}{c}\text { Kelas } \\
\text { Eks. I }\end{array}$ & $\begin{array}{c}\text { Kelas } \\
\text { Eks. II }\end{array}$ \\
\hline $1,78-2,08$ & 1,93 & 0 & 2 \\
$2,09-2,39$ & 2,24 & 1 & 1 \\
$2,40-2,70$ & 2,55 & 2 & 0 \\
$2,71-3,01$ & 2,86 & 14 & 7 \\
$3,02-3,32$ & 3,17 & 10 & 11 \\
$3,33-3,63$ & 3,48 & 3 & 7 \\
$3,64-3,94$ & 3,79 & 2 & 4 \\
\hline \multicolumn{2}{c}{ Jumlah } & 32 & 32 \\
\hline
\end{tabular}

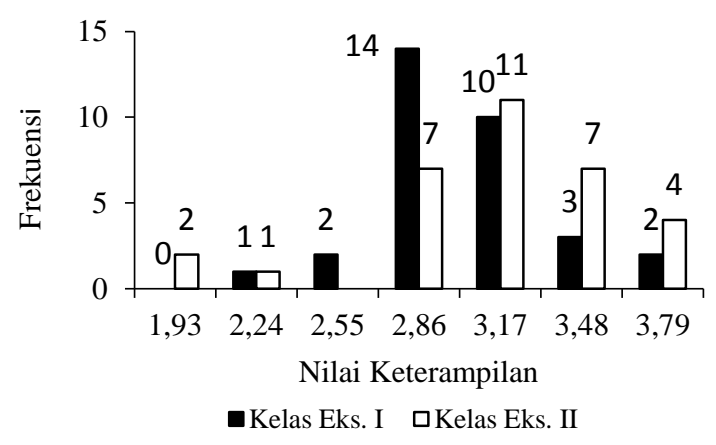

Gambar 3. Histogram Perbandingan Distribusi Frekuensi Nilai Aspek Keterampilan Siswa

Kesimpulan uji hipotesis menggunakan uji Kruskall Wallis tersaji pada Tabel 6, Tabel 7, dan Tabel 8.

\section{a. Hipotesis Pertama}

$\mathrm{H}_{\mathrm{OA}}$ : Tidak ada pengaruh penerapan model pembelajaran discoveryinquiry terbimbing dan bebas termodifikasi terhadap prestasi belajar siswa pada materi hidrolisis garam

$\begin{aligned} \mathrm{H}_{1 \mathrm{~A}} & \text { : Ada pengaruh penerapan model } \\ \text { pembelajaran discovery-inquiry } & \\ \text { terbimbing dan } & \text { bebas } \\ \text { termodifikasi terhadap prestasi } & \\ \text { belajar siswa pada materi } & \\ \text { hidrolisis garam } & \end{aligned}$

Tabel 6. Ringkasan Uji Hasil Hipotesis Pertama

\begin{tabular}{|c|c|c|c|}
\hline \multirow{2}{*}{$\begin{array}{c}\text { Aspek } \\
\text { Prestasi }\end{array}$} & \multicolumn{2}{|c|}{ Harga Sig. } & \multirow{2}{*}{ Keputusan } \\
\hline & Uji & Acuan & \\
\hline Pengetahuan & 0,695 & 0,050 & $\begin{array}{c}\mathrm{H}_{0} \\
\text { diterima }\end{array}$ \\
\hline Sikap & 0,132 & 0,050 & \\
\hline Keterampilan & 0,109 & 0,050 & $\begin{array}{c}\mathrm{H}_{0} \\
\text { diterima }\end{array}$ \\
\hline
\end{tabular}

Hasil pengujian hipotesis pertama menunjukkan nilai signifikansi untuk prestasi aspek pengetahuan, sikap dan keterampilan masing-masing adalah $0,695,0,132,0,109$. Nilai signifikansi yang diperoleh $>\alpha(0,050)$ sehingga $\mathrm{H}_{0 \mathrm{~A}}$ diterima. Hasil tersebut menyimpulkan bahwa tidak ada perbedaan prestasi belajar pada materi hidrolisis garam antara siswa yang diberi model pembelajaran discovery-inquiry terbimbing dan bebas termodifikasi.

Model pembelajaran merupakan faktor eksternal penentu keberhasilan pembelajaran yang dituangkan dalam nilai hasil belajar. Tidak adanya perbedaan prestasi belajar aspek pengetahuan pada materi pokok hidrolisis garam terhadap penggunaan kedua model pembelajaran disebabkan karena pada dasarnya sintak atau langkah-langkah pembelajaran dari kedua model pembelajaran ini hampir sama dengan prinsip yang sama pula. Hal tersebut karena adanya intervalensi dalam kedua model pembelalajaran, karena dalam model pembelajaran discoveryinquiry, dimana siswa menggali konsep dalam menemukan suatu pengetahuan yang baru. Pada model pembelajaran discovery-inquiry, baik terbimbing maupun bebas termodifikasi tahapan pembelajarannya menggunakan sistem dan metode aplikatif yang hampir sama yaitu melalui pengamatan, tinjauan pustaka, eksperimen, dan kerja proyek, sehingga hasil yang diperoleh tidak berpengaruh 
banyak terhadap hasil pengukuran akhir prestasi belajar siswa aspek pengetahuan.

Pada aspek sikap, pengembangan sikap sebagai proses pengembangan moral dan perilaku dilakukan oleh seluruh mata pelajaran disekolah dan dalam setiap kegiatan yang terjadi dikelas, sekolah dan masyarakat [15]. Hal ini memungkinkan menjadi variabel luaran yang kemungkinan memberikan pengaruh yang besar terhadap prestasi belajar siswa aspek sikap, selain itu pembentukan nilai dan sikap membutuhkan waktu yang relatif lebih lama daripada kompetensi yang lainnya. Penelitian ini dilakukan tiga kali tatap muka, sehingga tidak terjadi perubahan besar terhadap nilai sikap yang dimiliki oleh siswa dalam sampel penelitian.

Aspek keterampilan siswa dinilai berdasarkan sikap mereka ketika melakukan praktikum, diskusi dan presentasi serta hasil nilai laporan praktikum yang telah dibuat oleh siswa. Siswa melakukan kegiatan praktikum, siswa dibagi menjadi 8 kelompok dan dibagikan petunjuk praktikum berupa lembar kerja kelompok pada setiap kelompok. Dalam penyusunan laporan rata-rata siswa dalam kelompok memiliki jawaban yang sama, sehingga model pembelajaran tidak memberikan pengaruh yang signifikan terhadap prestasi belajar aspek keterampilan.

\section{b. Hipotesis Kedua}

$\mathrm{H}_{\mathrm{OB}}$ : Tidak ada pengaruh sikap ilmiah tinggi dan rendah terhadap prestasi belajar siswa pada materi hidrolisis garam

$\mathrm{H}_{1 \mathrm{~B}}$ : Ada pengaruh sikap ilmiah tinggi dan rendah terhadap prestasi belajar siswa pada materi hidrolisis garam

Tabel 7. Ringkasan Uji Hasil Hipotesis Kedua

\begin{tabular}{cccc}
\hline Aspek & \multicolumn{2}{c}{ Harga Sig. } & Keputusan \\
\cline { 2 - 3 } Prestasi & Uji & Acuan & Kepan \\
Pengetahuan & 0,277 & 0,050 & $\mathrm{H}_{0}$ \\
Siterima & & & $\mathrm{H}_{0}$ \\
Keterampilan & 0,270 & 0,050 & $\begin{array}{c}\text { diterima } \\
\mathrm{H}_{0} \\
\text { ditolak }\end{array}$ \\
\hline
\end{tabular}

Hasil pengujian hipotesis kedua menunjukkan nilai signifikansi untuk prestasi aspek pengetahuan, sikap dan keterampilan masing-masing adalah $0,277,0,270,0,030$. Nilai signifikansi yang diperoleh untuk prestasi belajar aspek pengetahuan dan sikap $>\alpha \quad(0,050)$ sehingga $\mathrm{H}_{\mathrm{OA}}$ diterima, sedangkan prestasi belajar aspek keterampilan < $\alpha(0,050)$ sehingga $\mathrm{H}_{\mathrm{OA}}$ ditolak. Hasil tersebut menyimpulkan bahwa tidak ada perbedaan prestasi belajar aspek pengetahuan dan sikap, sedangkan pada prestasi belajar aspek keterampilan terdapat perpedaan pengaruh pada materi hidrolisis garam antara siswa yang diberi model pembelajaran discovery-inquiry terbimbing dan bebas termodifikasi.

Pengukuran sikap ilmiah aspekaspek yang diukur tidak berpengaruh langsung terhadap prestasi aspek pengetahuan. Sikap ilmiah menunjukkan sikap siswa dalam penemuan, sedangkan prestasi belajar siswa aspek pengetahuan adalah pengukuran apa yang diperoleh siswa selama proses, selain itu siswa mengisi angket sikap ilmiah tidak bersungguh-sungguh, sehingga belum tentu siswa yang memiliki sikap ilmiah tinggi maka nilai pengetahuannya juga tinggi.

Siswa yang memiliki sikap ilmiah tinggi belum tentu mempunyai prestasi belajar aspek sikap yang lebih baik daripada siswa yang memiliki sikap ilmiah rendah. Siswa yang memiliki sikap ilmiah rendah biasanya cenderung memilih jawaban angket yang bernilai negatif sehingga menyebabkan prestasi belajar aspek sikapnya lebih rendah dibandingkan siswa yang memiliki sikap ilmiah tinggi. Namun hal ini berbeda dengan hasil penelitian yang diperoleh. Hal tersebut dibuktikan dengan adanya siswa yang memperoleh kategori skor sikap ilmiah rendah tetapi nilai sikap 3,00. Sedangkan siswa yang memperoleh sikap ilmiah tinggi tetapi nilai sikapnya 2,00.

Kegiatan eksperimen di laboratorium memiliki pengaruh positif terhadap keterampilan siswa. Kegiatan praktikum digunakan untuk menumbuhkan sikap ilmiah siswa pada prestasi belajar aspek keterampilan. Siswa yang memiliki sikap ilmiah tinggi lebih antusias dalam 
melakukan percobaan pada saat praktikum. Siswa tidak ragu mencoba alatalat praktikum tanpa rasa takut salah dan kaku, mencoba hal-hal baru misalnya cara menggunakan kertas stik $\mathrm{pH}$ sehingga diperoleh $\mathrm{pH}$ yang sesuai dengan teori yang ada bahkan mengulang percobaan jika dirasa hasil yang diperoleh kurang sesuai. Siswa selama proses pembelajaran berlangsung terlihat lebih aktif dan kooperatif terhadap kegiatan praktikum, sehingga kerja motorik siswa lebih dominan dalam penilaian aspek keterampilan oleh observer. Pengamatan inilah yang menyebabkan penilaian terhadap aspek keterampilan siswa menjadi lebih tinggi untuk siswa yang memiliki sikap ilmiah tinggi dibandingkan dengan siswa yang memiliki sikap ilmiah rendah. Siswa yang memiliki sikap ilmiah rendah cenderung pasif dan malas dalam melakukan kegiatan praktikum.

\section{c. Hipotesis Ketiga}

$\mathrm{H}_{O A B}$ : Tidak ada interaksi antara model pembelajaran discovery-inquiry terbimbing dan bebas termodifikasi dengan sikap ilmiah siswa terhadap prestasi belajar siswa pada materi hidrolisis garam

$\mathrm{H}_{1 \mathrm{AB}}$ : Ada interaksi antara model pembelajaran discovery-inquiry terbimbing dan bebas termodifikasi dengan sikap ilmiah siswa terhadap prestasi belajar siswa pada materi hidrolisis garam

Tabel 8. Ringkasan Uji Hasil Hipotesis Ketiga

\begin{tabular}{|c|c|c|c|}
\hline \multirow{2}{*}{$\begin{array}{c}\text { Aspek } \\
\text { Prestasi }\end{array}$} & \multicolumn{2}{|c|}{ Harga Sig. } & \multirow[b]{2}{*}{ Keputusan } \\
\hline & Uji & Acuan & \\
\hline Pengetahuan & 0,328 & 0,050 & $\begin{array}{c}\mathrm{H}_{0} \\
\text { diterima }\end{array}$ \\
\hline Sikap & 0,257 & 0,050 & $\begin{array}{c}\mathrm{H}_{0} \\
\text { diterima }\end{array}$ \\
\hline Keterampilan & 0,211 & 0,050 & $\begin{array}{c}\mathrm{H}_{0} \\
\text { diterima }\end{array}$ \\
\hline
\end{tabular}

Hasil pengujian hipotesis ketiga menunjukkan nilai signifikansi untuk prestasi aspek pengetahuan, sikap dan keterampilan masing-masing adalah $0,328,0,257,0,211$. Nilai signifikansi yang diperoleh $>\alpha(0,050)$ sehingga $\mathrm{H}_{0 \mathrm{~A}}$ diterima. Hasil tersebut menyimpulkan bahwa penggunaan model pembelajaran discovery-inquiry terbimbing dan bebas termodifikasi tidak berinteraksi dengan sikap ilmiah terhadap prestasi belajar siswa pada materi hidrolisis garam.

Nilai rerata aspek pengetahuan pada model discovery-inquiry learning terbimbing dengan sikap ilmiah tinggi adalah 86,363 dan model discoveryinquiry learning terbimbing dengan sikap ilmiah rendah adalah 65,667, sedangkan model discovery-inquiry learning bebas termodifikasi dengan sikap ilmiah tinggi 89,206 dan model discovery-inquiry learning bebas termodifikasi dengan sikap ilmiah rendah 64,545. Data tersebut menunjukkan bahwa pada model pembelajaran yang digunakan, siswa yang memiliki sikap ilmiah tinggi tetap memperoleh nilai lebih tinggi daripada siswa yang memiliki sikap ilmiah rendah.

Pembentukan nilai dan sikap membutuhkan waktu yang cukup lama, selain itu pembelajaran menggunakan model tidak berdampak langsung terhadap pembentukan sikap siswa [16]. Menurut teori Vygotsky pembelajaran ditekankan pada lingkungan sosial bukan melalui model yang dimiliki siswa. Lingkungan sosial yang dimaksudkan disini adalah guru sebagai fasilitator dan teman sejawat ketika berdiskusi, sehingga dapat disimpulkan bahwa tidak terdapat interaksi antara model pembelajaran discoveryinquiry terbimbing dan bebas termodifikasi dengan sikap ilmiah tinggi dan sikap ilmiah rendah terhadap prestasi belajar aspek sikap siswa.

Aspek keterampilan tidak terdapat interaksi antara sikap ilmiah dan model pembelajaran terhadap prestasi belajar karena pengukuran aspek sikap tidak dilakukan ke dalam aspek-aspek yang detail karena perbedaan penggunaan dan pengalaman [17]. Oleh karena itu, apapun pendekatan dan model pembelajaran yang digunakan, siswa yang memiliki sikap ilmiah tinggi akan mempunyai prestasi belajar aspek keterampilan yang lebih tingg jika dibandingkan dengan siswa yang memiliki sikap ilmiah rendah. 


\section{KESIMPULAN}

Kesimpulan dari hasil penelitian ini antara lain (1) tidak terdapat perbedaan prestasi belajar siswa antara siswa yang diberi model pembelajaran discoveryinquiry terbimbing dan bebas termodifikasi; (2) Terdapat perbedaan prestasi belajar siswa pada aspek keterampilan antara siswa yang memiliki sikap ilmiah tinggi dan sikap ilmiah rendah, sedangkan aspek pengetahuan dan sikap tidak; dan (3) tidak terdapat interaksi antara penggunaan model pembelajaran discovery-inquiry terbimbing dan bebas termodifikasi dengan sikap ilmiah terhadap prestasi belajar siswa.

\section{UCAPAN TERIMA KASIH}

Penulis menyadari dalam penelitian dan penyusunan skripsi ini banyak mendapatkan petunjuk dan bantuan dari berbagai pihak. Dengan segala kerendahan hati penulis mengucapkan terima kasih kepada: (1) Drs. Agung Wardoyo selaku Kepala SMA N 1 Boyolali, (2) Drs. Sumardi dan Dra. Endang Jatiningsih selaku guru mata pelajaran Kimia SMA N 1 Boyolali.

\section{DAFTAR RUJUKAN}

[1] Kementrian Pendidikan dan Kebudayaan. (2014). Kurikulum 2013. Jakarta: Kemendikbud.

[2] Fadlillah, M. (2014). Implementasi Kurikulum 2013. Yogyakarta: Ar-Dzat Media.

[3] Sari, M. (2013). Problematika Pembelajaran Sains Ditinjau dari Problematika Guru. Jurnal Al-Ta'lim, 1 (4), 346-356.

[4] Mukhopadhay. (2014). Scientific attitude-some psychometric considerations. IOSR Journal Of Humanities And Social Science (IOSR-JHSS). 19 (7), 98-100

[5] Lestari, T. (2012). Pembelajaran Kimia dengan Inkuiri Terbimbing Melalui Metode Eksperimen dan. Demonstrasi Ditinjau dari
Kemampuan Awal dan Sikap Ilmiah Siswa. Tesis. Surakarta: Program Studi Pendidikan Sains Pascasarjana UNS.

[6] Kirschner, Paul A., etc. (2006). Why Minimal Guidance During Instruction Does Not Work: An Analysis of the Failure of Construtivist. Discovery, Problem Based, Experiental and Inquiry-Based Teaching. Educational Psychologist, 4 (2), 75-86.

[7] Eggen, P. D dan Kaucak, D.P. (1996). Startegies for Teachers Teaching Content and Thingking Skills Third Edition. Boston: Allyn \& Bacon

[8] Bell, Randy, etc. (2005). The Scientific Teacher: Simplifying Inquiry Instruction. The Nation Science Education Standards. Washington, DC: National Acdemy Press.

[9] Suparno, Paul. (2007). Metodologi Pembelajaran Fisika Kontruktivistik dan Menyenangkan. Skripsi. Yogyakarta: Universitas Sanata Darma

[10] Rokhayati, N. (2010). Peningkatan Penguasaan Konsep Matematika Melalui Pembelajaran Guided Discovery-Inquiry Pada Siswa Klas VII SMP $N 1$ Sleman. Skripsi. Yogyakarta: UNY.

[11] Suprini. (2012). Analisis Keterampilan Proses Sains Siswa Kelas XI Pada Materi Pembelajaran Sifat-sifat Koloid Menggunakan Metode DiscoveryInquiry. Skripsi. Bandung: UPI.

[12] Wahyuningsih. (2012). Peningkatan Proses dan Hasil Belajar IPA Materi Penggolongan Daun dengan Metode Penemuan Terbimbing. Jurnal Pendidikan Tindakan Kelas 3 (2). Semarang: UNNES

[13] Slameto. (2010). Belajar dan Faktorfaktor yang Memepengaruhinya. Jakarta: Bumi Aksara 
[14] Widya, L., Ashadi., dan Nurhayati, N. (2012). Jurnal Pendidikan Kimia, 2 (2), 19-24

[15] Nulfita, I, M. (2014). Impelmentasi Pendekatan Saintifik dan Karakter dalam Pembelajaran Sains Menyongsong Generasi Emas Indonesia. Jurnal Pendidikan UNS. 1-7.
[16] Indrayanti, N., Ariani, S., dan Haryono. (2014). Jurnal Pendidikan Kimia, 3 (4), 2014

[17] Wijayanto, H., Utomo, S., dan Haryono. (2017). Jurnal Pendidikan Kimia, 6 (1), 2017. 